\title{
Peningkatan Kemampuan Pemahaman Matematis Siswa melalui Pembelajaran Kooperatif Teknik Kancing Gemerencing dan Number Head Together
}

\author{
Dina Nailul Muna ${ }^{1}$ \\ STKIP Garut \\ Ekasatya Aldila Afriansyah ${ }^{2}$ \\ STKIP Garut \\ e-mail: $\underline{\text { e_satya@yahoo.com }}$
}

\begin{abstract}
ABSTRAK
Metode yang digunakan dalam penelitian ini adalah metode kuasi eksperimen dengan menggunakan dua kelas, yaitu kelas kuasi eksperimen I dan kelas kuasi eksperimen II. Populasinya adalah seluruh siswa kelas VII SMP Negeri 5 Garut tahun ajaran 2014/2015, sedangkan sampelnya yaitu kelas VII-H sebagai kelompok kuasi eksperimen I yang mendapatkan pembelajaran kancing gemerincing dan kelas VII-F sebagai kelompok kuasi eksperimen II yang mendapatkan pembelajaran NHT dengan pengambilan sampel secara purposive, yaitu pengambilan sampel dengan pertimbangan tertentu. Instrumen yang digunakan adalah tes kemampuan pemahaman matematis dan angket siswa. Berdasarkan hasil penelitian, diketahui bahwa: (1) Terdapat perbedaan peningkatan kemampuan pemahaman matematis siswa antara yang mendapatkan model pembelajaran kooperatif teknik Numbered Head Together (NHT) dengan kancing gemerincing, (2) Kualitas peningkatan kemampuan pemahaman matematis siswa kelas kuasi eksperimen I dengan teknik pembelajaran kancing gemerincing adalah sedang, (3) Kualitas peningkatan kemampuan pemahaman matematis siswa kelas kuasi eksperimen II dengan teknik pembelajaran NHT adalah sedang, (4) Siswa bersikap positif terhadap teknik pembelajaran kancing gemerincing, (5) Siswa bersikap positif terhadap teknik pembelajaran NHT namun di sisi lainmereka bersikap negatif terhadap penyediaan LKS.
\end{abstract}

Kata kunci: Kemampuan Pemahaman Matematis, metode kuasi eksperimen, pembelajaran kooperatif, teknik Kancing Gemerincing, teknik Numbered Head Together

\section{ABSTRACT}

The method that used of this research is quasi experiment make use of two classes, quasi experiment I and quasi experiment II. The population is all of sevent grade students at SMPN 5 Garut period 2014/2015, and the sample is H-sevent grade as quasi experiment I who get kancing gemerincing learning and F-sevent grade as quasi experiment II who get NHT learning with purposive sampling. The purposive sampling is sampling based on certain considerations. The instrument of this research is mathematical understanding skill test and questionnaire. Based on the result of research, known that: (1) found the difference increased of mathematical understanding skill students between who get strategy cooperative learning technique Numbered Head Together (NHT) and kancing gemerincing, (2) the increased quality of mathematical understanding skill quasi experiment I students with technique kancing gemerincing is enough, (3) the increased quality of mathematical understanding skill quasi experiment II students with technique NHT is enough, (5) the student were gived their positive attitude to technique kancing gemerincing, (5) the student were gived their positive attitude to technique NHT, but they were gived their negative attitude to equipping of LKS.

Keywords: Mathematical Understanding Ability, quasi experiment method, cooperative learning, Kancing Gemerincing technique, and Number Head Together technique

\section{PENDAHULUAN}

Matematika adalah salah satu ilmu pengetahuan yang banyak memberikan kontribusi dalam kehidupan sehari-hari, seperti dinyatakan oleh Suherman dan
Winataputra (Huda dan Kencana , 2013:1) 'kontribusi yang diberikan matematika mulai dari hal yang sederhana seperti perhitungan dasar (basic calculation) sampai hal yang kompleks dan abstrak seperti penerapan 
analisis numerik dalam bidang teknik dan sebagainya'.

Ketidakpahaman terhadap matematika membuat kontribusi yang dimaksud sulit terwujud. Namun, hal tersebut tidak akan terjadi, jika sumber daya manusia yang ada benar-benar mampu memanfaatkan kemampuannya untuk memahami dengan benar matematika itu sendiri. Kemampuan pemahaman terhadap matematika ini harus diasah dan diterapkan dari dini dengan bantuan pendidikan formal maupun non formal..

Indikator kemampuan pemahaman matematis secara umum menurut Sumarmo (Natawidjaja, 2007: 682) meliputi mengenal, memahami dan menerapkan konsep, prosedur, prinsip serta ide matematika. Lebih lanjut Kilptric dan Findell (Rifyal, 2013: 10) mengemukakan bahwa indikator kemampuan pemahaman matematis siswa terhadap suatu konsep meliputi beberapa hal yaitu:

1. Kemampuan menyebutkan kembali konsep yang diperoleh dengan bahasanya sendiri.

2. Kemampuan menggunakan, memanfaatkan, dan memilih prosedur atau operasi tertentu dari suatu konsep secara algoritma serta mengaplikasikannya dalam pemecahan masalah.

3. Kemampuan menerjemahkan suatu permasalahan ke dalam bahasa matematis.

4. Kemampuan mengaitkan suatu konsep matematika baik dengan konsep matematika lagi maupun dengan konsep di luar matematika.

Pemahaman matematis ini bisa ditunjang dengan pemberian model pembelajaran yang sesuai dengan perkembangan kognitif siswa, seperti dikatakan oleh Piaget pada tahapan perkembangan kognitif usia 7 s.d 14 tahun, “ ... Permainan kelompok termasuk kesepakatan tentang peraturan dan kerjasama berdasarkan peraturan ... " (Yamin, 2013:
142). Sehingga, untuk jenjang usia 7 s.d 14 tahun atau sekitar SD sampai SMP model pembelajaran yang bisa diberikan atau diterapkan dalam pembelajaran di kelas adalah pembelajaran yang bersifat kelompok (Cooperative Learning).

Dalam cooperative learning siswa mempunyai kesempatan untuk saling bertukar pendapat, bertukar pemikiran, saling membantu dalam penyelesaian tugas dan memunculkan sikap tanggung jawab, kerjasama, serta ketergantungan positif satu sama lain. Terdapat banyak teknik pembelajaran kooperatif, salah satunya adalah kancing gemerincing dan Numbered Head Together (NHT).

Dalam teknik kancing gemerincing, siswa diberikan kancing dan dirangsang untuk menghabiskan kancing yang dimiliki dengan cara mengemukakan pendapat, menanggapi pendapat dan menyelesaikan permasalahan yang diberikan, sehingga siswa mampu berkomunikasi, memahami materi, berpikir kreatif dan bertindak cepat secara berkelompok. Sedangkan dalam NHT masing-masing siswa dalam kelompok diberikan nomor dan dirangsang untuk berpikir bersama mengenai materi atau tugas yang diberikan sampai akhirnya guru mengundi nomor siswa yang akan mempresentasikan tugas tersebut di depan kelas, sehingga siswa dalam kelompok termotivasi untuk mempresentasikan tugas dengan sebaik-baiknya dengan cara berkomunikasi, memahami tugas dan berpikir tepat dalam masing-masing kelompok.

Berdasarkan uraian di atas, penulis terdorong untuk meneliti mengenai kemampuan pemahaman matematis antara siswa yang diberikan model pembelajaran kooperatif teknik kancing gemerincing dengan Numbered Head Togetether (NHT).

Rumusan masalah dalam penelitian ini adalah sebagai berikut:

1. Apakah terdapat perbedaan peningkatan kemampuan pemahaman matematis 
siswa antara yang mendapatkan model pembelajaran kooperatif teknik kancing gemerincing dengan NHT?

2. Apakah interpretasi kualitas peningkatan kemampuan pemahaman matematis siswa setelah diberikan model pembelajaran kooperatif teknik kancing gemerincing dan model pembelajaran kooperatif teknik NHT?

Selain rumusan masalah di atas, peneliti juga merumuskan pemasalahan sebagai berikut:

1. Apakah interpretasi sikap siswa terhadap model pembelajaran kooperatif teknik kancing gemerincing dan model pembelajaran kooperatif teknik NHT?

\section{Kemampuan Pemahaman Matematis}

Qohar (2009: 456) menyatakan bahwa kemampuan pemahaman matematis adalah kemampuan mengklasifikasikan obyek-obyek matematika, menginterpretasikan gagasan atau konsep, menemukan contoh dari sebuah konsep, memberikan contoh dan bukan contoh dari sebuah konsep dan menyatakan kembali konsep matematika dengan bahasa sendiri.

Indikator kemampuan pemahaman matematis secara umum menurut Sumarmo (Natawidjaja, 2007: 682) meliputi mengenal, memahami dan menerapkan konsep, prosedur, prinsip serta ide matematika.

Lebih lanjut Kilptric dan Findell (Rifyal, 2013: 10) mengemukakan bahwa indikator kemampuan pemahaman matematis siswa terhadap suatu konsep meliputi beberapa hal yaitu:

1. Kemampuan menyebutkan kembali konsep yang diperoleh dengan bahasanya sendiri.

2. Kemampuan menggunakan, memanfaatkan, dan memilih prosedur atau operasi tertentu dari suatu konsep secara algoritma serta mengaplikasikannya dalam pemecahan masalah.
3. Kemampuan menerjemahkan suatu permasalahan ke dalam bahasa matematis.

4. Kemampuan mengaitkan suatu konsep matematika baik dengan konsep matematika lagi maupun dengan konsep di luar matematika.

\section{Model Pembelajaran Kooperatif Teknik Kancing Gemerincing}

Model pembelajaran kooperatif adalah model pembelajaran berkelompok yang mengutamakan kerjasama untuk mencapai tujuan pembelajaran (Majid, 2013: 174).

Teknik kancing gemerincing dikembangkan oleh Spencer Kagan (Lie, 2008: 63). Teknik kancing gemerincing ini dikembangkan karena adanya ketimpangan antara siswa yang berkemampuan rendah dan berkemampuan tinggi.

Langkah-langkah pembelajaran teknik kancing gemerincing (Lie, 2008: 64) adalah sebagai berikut:

1. Guru menyiapkan satu kotak kecil yang berisi kancing-kancing atau benda-benda kecil lainnya

2. Sebelum kelompok memulai tugasnya, setiap siswa dalam masing-masing kelompok mendapatkan dua atau tiga buah kancing (jumlah kancing bergantung pada sukar tidaknya tugas yang diberikan)

3. Setiap kali seorang siswa berbicara atau mengeluarkan pendapat, dia harus menyerahkan salah satu kancingnya dan meletakannya ditengah-tengah kelompok.

4. Jika kancing yang dimiliki siswa sudah habis, maka ia tidak boleh berbicara sampai semua temannya menghabiskan kancing mereka.

5. Jika semua kancing telah habis, sedangkan tugas belum selesai, kelompok boleh mengambil kesepakatan untuk membagikan kancing dan mengulang prosedurnya kembali 


\section{Model Pembelajaran Kooperatif Teknik Numbered Head Together (NHT)}

NHT dikembangkan oleh Spencer Kagen (1993) dengan tujuan untuk melibatkan lebih banyak siswa dalam menelaah materi yang tercakup dalam suatu pembelajaran dan mengecek pemahaman mereka terhadap isi pembelajaran tersebut (Majid, 2013: 192)

Langkah-langkah pembelajaran NHT (Majid, 2013: 192) adalah :

1. Penomoran

Guru membagi siswa kedalam kelompok yang beranggota $3-5$ orang dan setiap anggota kelompok diberi nomor $1-5$.

2. Mengajukan Pertanyaan

Guru mengajukan pertanyaan kepada siswa dan pertanyaan tersebut dapat bervariasi. Pertanyaan bisa sangat spesifik dan dalam bentuk kalimat tanya, atau berbentuk arahan.

\section{Berpikir Bersama}

Siswa menyatukan pendapatnya terhadap jawaban pertanyaan tersebut dan meyakinkan tiap anggota kelompok mengetahui jawaban tersebut.

\section{Menjawab}

Guru memanggil atau mengundi satu nomor tertentu, kemudian siswa yang nomornya sesuai harus mengacungkan tangannya dan mecoba untuk menjawab pertanyaan untuk seluruh kelas.

\section{METODE}

Desain penelitian yang digunakan adalah desain penelitian berbentuk the static group pretest-postest design dan dapat diformulasikan sebagai berikut :

$$
\begin{aligned}
& \mathrm{A} \rightarrow \mathrm{O} \rightarrow \mathrm{X}_{1} \rightarrow \mathrm{O} \\
& \mathrm{B} \rightarrow \mathrm{O} \rightarrow \mathrm{X}_{2} \rightarrow \mathrm{O}
\end{aligned}
$$

(Sukmadinata, $2007: 209$ )

Keterangan :

A : Kelas Kuasi Eksperimen I

B : Kelas Kuasi Eksperimen II

O : Pretest dan Postest
$\mathrm{X}_{1}$ : Pembelajaran dengan menggunakan teknik kancing gemerincing

$\mathrm{X}_{2}$ : Pembelajaran dengan menggunakan teknik Numbered Head Together (NHT)

Populasi dalam penelitian ini adalah siswa kelas VII SMP Negeri 5 Garut Tahun Ajaran 2014/2015.

Sampel dari penelitian ini diambil secara purposive, yaitu pemilihan sampel dengan pertimbangan bahwa kedua kelas tersebut memiliki masalah dalam hal pemahaman terhadap matematika. Dari 9 kelas, diambil dua kelas, yaitu kelas VII - H sebagai kelas kuasi eksperimen I dengan teknik pembelajaran kancing gemerincing dan VII F sebagai kelas kuasi eksperimen II dengan teknik pembelajaran NHT.

Penelitian dilaksanakan pada tanggal 6 s.d 31 Januari 2015. Penelitian dilaksanakan di SMP Negeri 5 Garut Jl. Gunung Payung No. 36.

\section{Teknik Pengumpulan Data}

Untuk mengumpulkan data penelitian, digunakan tes dan angket sebagai instrumen pengumpulan data. Sebelum penelitian dilakukan, terlebih dahulu dilakukan uji coba instrumen dan didapat tujuh soal kemampuan pemahaman yang layak digunakan sebagai instrumen penelitian yang telah teruji validitas, reliabilitas, daya pembeda dan tingkat kesukarannya.

Tes ini diberikan pada saat sebelum (pretest) dan sesudah (postest) pembelajaran dilaksanakan untuk mengetahui perbedaan peningkatan kemampuan pemahaman matematis siswa antara yang mendapatkan teknik kancing gemerincing dan NHT. Sedangkan angket digunakan untuk mengetahui sikap siswa terhadap teknik pembelajaran kancing gemerincing dan NHT. 


\section{Teknik Analisis Data}

Hasil pretest, postest dan angket yang diperoleh dari kelas kuasi eksperimen I dan kuasi eksperimen II diolah dengan analisis statistik menggunakan uji dua sampel saling bebas (independent), uji gain ternormalisasi dan skala sikap.

\section{HASIL DAN PEMBAHASAN Analisis Data Pretest Siswa}

Tabel 1. Rata-Rata Hitung dan Simpangan Baku Pretest

\begin{tabular}{|c|c|c|c|c|}
\hline Kelas & $\begin{array}{c}\text { Banyak } \\
\text { Siswa }\end{array}$ & $\begin{array}{c}\text { Skor } \\
\text { Ideal }\end{array}$ & $\begin{array}{c}\text { Rata } \\
- \text { rata } \\
(\overline{\mathbf{x}})\end{array}$ & $\begin{array}{c}\text { Simpangan } \\
\text { Baku (s) }\end{array}$ \\
\hline $\begin{array}{c}\text { Eksperimen } \\
\text { I }\end{array}$ & 35 & 28 & 5,26 & 2,47 \\
\hline $\begin{array}{c}\text { Eksperimen } \\
\text { II }\end{array}$ & 34 & 28 & 10,09 & 3,85 \\
\hline
\end{tabular}

Dari tabel 1 tersebut didapat bahwa ratarata kelas kuasi eksperimen II lebih dari ratarata kelas kuasi eksperimen I yaitu 10,09 > 5,26 dari skor ideal 28. Dengan menguji normalitas kedua kelas, didapat bahwa kedua kelas tesebut berdistribusi normal namun memiliki varians yang tidak homogen. Selanjutnya, dengan menggunakan uji t' pada taraf signifikansi 5\% didapat bahwa terdapat perbedaan kemampuan awal yang signifikan antara kelas kuasi eksperimen I dan kuasi eksperimen II.

\section{Teknik Analasis Postest}

Tabel 2. Rata-Rata Hitung dan Simpangan Baku Postest

\begin{tabular}{|c|c|c|c|c|}
\hline Kelas & $\begin{array}{c}\text { Banyak } \\
\text { Siswa }\end{array}$ & $\begin{array}{c}\text { Skor } \\
\text { Ideal }\end{array}$ & $\begin{array}{c}\text { Rata } \\
- \text { rata } \\
(\overline{\mathbf{x}})\end{array}$ & $\begin{array}{c}\text { Simpangan } \\
\text { Baku (s) }\end{array}$ \\
\hline $\begin{array}{c}\text { Eksperimen } \\
\text { I }\end{array}$ & 33 & 28 & 11,63 & 4,31 \\
\hline $\begin{array}{c}\text { Eksperimen } \\
\text { II }\end{array}$ & 34 & 28 & 18,11 & 6,01 \\
\hline
\end{tabular}

Dari tabel 2 tersebut didapat bahwa ratarata kelas kuasi eksperimen II lebih dari ratarata kelas kuasi eksperimen I yaitu 18,11 > 11,63 dari skor ideal 28.
Karena pada pretest telah menunjukan bahwa terdapat perbedaan kemampuan dari kedua kelas, yaitu kelas kuasi eksperimen I dan kelas kuasi eksperimen II, maka pada postest, data yang didapat tidak dianalisis lebih lanjut melalui analisis postest, namun dilanjutkan ke analisis peningkatan (Gain) dari kedua kelas tersebut menggunakan Uji Gain Ternormalisasi

\section{Uji Gain Ternormalisasi}

Tabel 3. Rata-Rata dan Simpangan Baku Nilai Gain Ternormalisasi Kedua Kelas

\begin{tabular}{|c|c|c|c|}
\hline Kelas & $\begin{array}{c}\text { Banyak } \\
\text { Siswa }\end{array}$ & $\begin{array}{c}\text { Rata-rata Nilai } \\
\text { Gain } \\
\text { Ternormalisasi }\end{array}$ & $\begin{array}{c}\text { Simpangan } \\
\text { Baku (s) }\end{array}$ \\
\hline $\begin{array}{c}\text { Eksperimen } \\
\text { I }\end{array}$ & 32 & 0,310 & 0,131 \\
\hline $\begin{array}{c}\text { Eksperimen } \\
\text { II }\end{array}$ & 33 & 0,519 & 0,155 \\
\hline
\end{tabular}

Dari tabel 3 tersebut didapat bahwa untuk kelas kuasi eksperimen I, didapat ratarata nilai gain ternormalisasi 0,310 , sehingga kualitas peningkatan kemampuan pemahaman siswa dari sebelum sampai sesudah pembelajaran berada pada kualitas peningkatan yang sedang. Sedangkan untuk kelas kuasi eksperimen II, didapat rata-rata nilai gain ternormalisasi 0,519, sehingga kualitas peningkatan kemampuan pemahaman siswa dari sebelum sampai sesudah pembelajaran berada pada kualitas peningkatan yang sedang pula.

Dengan menguji normalitas kedua kelas, didapat bahwa kedua kelas tesebut berdistribusi normal dan memiliki varians yang homogen. Selanjutnya, dengan menggunakan uji t pada taraf signifikansi 5\% didapat bahwa terdapat perbedaan peningkatan kemampuan pemahaman matematis siswa antara yang mendapatkan model pembelajaran kooperatif teknik Numbered Head Together (NHT) dengan kancing gemerincing. 


\section{Analisis Data Angket}

Tujuan dari angket ini adalah untuk mengetahui sikap siswa terhadap mata pelajaran matematika dengan menggunakan teknik pembelajaran kancing gemerincing dan NHT.

1. Sikap Siswa Terhadap Mata Pelajaran Matematika dan Teknik Pembelajaran Kancing Gemerincing

Pada angket ini, terdapat dua aspek dengan 6 indikator dan 10 pernyataan. Berdasarkan kriteria, didapat bahwa siswa bersikap positif terhadap semua indikator pada kedua aspek.

2. Sikap Siswa Terhadap Mata Pelajaran

Matematika dan Teknik Pembelajaran NHT

Pada angket ini, terdapat dua aspek dengan 6 indikator dan 10 pernyataan. Berdasarkan kriteria, didapat bahwa siswa bersikap positif terhadap semua indikator pada aspek sikap terhadap mata pelajaran matematika, namun di sisi lain mereka bersikap negatif terhadap indikator penyediaan LKS pada aspek sikap siswa terhadap teknik pembelajaran NHT.

\section{Pembahasan}

Setelah dilakukan analisis data ditemukan bahwa terdapat perbedaan kemampuan awal yang signifikan antara kelas kuasi eksperimen I dan kuasi eksperimen II. Dilihat dari nilai rata-rata pretest, kelas kuasi ekperimen II lebih unggul, hal tersebut bisa disebabkan oleh beberapa hal, diantaranya:

1. Waktu penelitian adalah minggu kedua semester II, sehingga siswa mempunyai beberapa kali pertemuan kosong yang oleh sebagian siswa digunakan untuk membaca atau mengingat kembali materi yang akan dipelajari (karena segiempat ini merupakan materi yang telah dipelajari di sekolah dasar)

2. Kelas kuasi eksperimen II cenderung lebih unggul dalam membaca atau mengingat kembali materi yang akan dipelajari dibandingkan kelas kuasi eksperimen I dilihat dari kemampuan menyelesaikan soal pretest dan pembelajaran di kelas yang mana siswa sering mengatakan bahwa materi tersebut telah dipelajari di sekolah dasar.

3. Siswa Kelas kuasi ekperimen II lebih mudah menerjemahkan soal daripada kelas kuasi eksperimen I.

Setelah itu dilanjutkan dengan pemberian materi dengan teknik pembelajaran kancing gemerincing kepada kelas kuasi eksperimen I dan teknik pembelajaran NHT kepada kelas kuasi eksperimen II.

Langkah selanjutnya yang dilakukan setelah pemberian materi adalah melakukan tes akhir (postest) untuk mengetahui peningkatan kemampuan pemahaman matematis siswa dari sebelum pembelajaran sampai sesudah pembelajaran dilaksanakan. Setelah analisis data dilakukan, ditemukan bahwa secara keseluruhan kelas kuasi eksperimen I dan kuasi eksperimen II meymmpunyai rata-rata peningkatan yang sedang dengan kesimpulan akhir terdapat perbedaan peningkatan kemampuan pemahaman matematis siswa antara yang mendapatkan teknik pembelajaran Numbered Head Together (NHT) dengan kancing gemerincing. Dilihat dari nilai rata-rata gain, kelas kuasi ekperimen II lebih unggul, hal tersebut disebabkan oleh beberapa hal, diantaranya:

1. Pada kegiatan mengamati, menanya, mencoba dan menalar dalam kelompok, kedua kelas melakukannya dengan baik dan antusias.

2. Kegiatan pembelajaran di kelas kuasi eksperimen II cenderung lebih hidup dan siswa banyak bertanya mengani hal yang belum mereka pahami dari lembar kerja siswa yang diberikan (LKS).

3. Pada kegiatan menyimpulkan atau mengomunikasikan, kelas kuasi eksperimen II lebih efektif dan kondusif daripada kelas kuasi eksperimen I, 
sehingga siswa pada kelas kuasi eksperimen II lebih mudah memahami materi.

Dari segi sikap siswa terhadap mata pelajaran matematika dan teknik pembelajaran yang digunakan, didapat bahwa pada kelas kuasi eksperimen I dengan teknik pembelajaran kancing gemerincing, siswa bersikap positif terhadap semua aspek dan indikator. Hal ini disebabkan oleh antusiasme siswa terhadap pembelajaran dengan menggunakan teknik pembelajaran yang baru serta mengalami hal-hal yang baru seperti pengisian LKS dan penggunaan kancing, sehingga minat dan motivasi siswa tumbuh untuk belajar dan memahami matematika.

Sedangkan pada kelas kuasi ekperimen II dengan teknik pembelajaran NHT, siswa bersikap positif pada semua aspek dan indikator kecuali pada satu indikator yaitu indikator mengenai pemberian LKS, yang mana siswa bersikap negatif terhadap indikator tersebut. Hal ini disebabakan karena siswa merasa kesulitan untuk memahami dan menyelesaikan permasalahan yang terdapat pada LKS yang diberikan, sehingga mereka sangat sering bertanya mengenai apa yang belum mereka pahami di LKS. Namun di sisi lain, mereka sangat antusias dalam pembelajaran dengan teknik pembelajaran yang baru serta mengalami hal-hal yang baru pula, seperti penyajian LKS dan penomoran siswa, sehingga mendorong siswa untuk meyakinkan setiap anggota kelompoknya dalam memahami apa yang terdapat pada LKS.

\section{PENUTUP}

\section{Kesimpulan}

Berdasarkan analisis dan kajian permasalahan dalam penelitian ini, maka secara umum dapat dikatakan bahwa hasil penelitian ini telah dapat menjawab permasalahan-permasalahan yang melatarbelakangi perlunya penelitian ini dilakukan.
Adapun kesimpulan yang dapat diambil dari hasil penelitian ini adalah :

1. Terdapat perbedaan peningkatan kemampuan pemahaman matematis siswa antara yang mendapatkan model pembelajaran kooperatif teknik Numbered Head Together (NHT) dengan kancing gemerincing.

2. Interpretasi kualitas peningkatan kemampuan pemahaman matematis siswa kelas kuasi eksperimen I dengan teknik pembelajaran kancing gemerincing adalah sedang; dan interpretasi kualitas peningkatan kemampuan pemahaman matematis siswa kelas kuasi eksperimen II dengan teknik pembelajaran NHT adalah sedang.

3. Interpretasi sikap siswa bersikap positif terhadap teknik pembelajaran kancing gemerincing; dan interpretasi sikap siswa bersikap positif terhadap teknik pembelajaran NHT namun di sisi lain mereka bersikap negatif terhadap penyediaan LKS.

\section{Saran}

Berdasarkan hasil penelitian dan kesimpulan mengenai kemampuan pemahaman matematis dengan teknik pembelajaran kancing gemerincing dan NHT, dapat diajukan beberapa saran sebagai berikut:

1. Guru dapat menggunakan teknik pembelajaran NHT sebagai alternatif dalam pembelajaran pada materi segiempat.

2. Melakukan perencanaan dengan matang sebelum pembelajaran menggunakan kancing gemerincing atau NHT dilaksanakan, karena pembelajaran dengan kedua teknik pembelajaran tersebut memerlukan waktu yang relatif lama. Hal ini dimaksudkan agar tujuan pembelajaran bisa tercapai dengan alokasi waktu yang tersedia. 
3. Pada pembelajaran NHT, penggunaan LKS bisa digantikan dengan hal yang lain namun esensi dari pembelajaran dengan NHT tersebut harus tetap sama.

4. Melanjutkan penelitian dengan teknik pembelajaran kancing gemerincing atau NHT pada aspek penelitian yang lain dengan kajian yang lebih luas

\section{DAFTAR PUSTAKA}

Huda, N dan Kencana, AG. (2013). Analisis Kesulitan Siswa Berdasarkan

KemampuanPemahaman dalam Menyelesaikan Soal Cerita pada Materi Kubus dan Balok Di Kelas VIII SMP Negeri 30 Muaro Jambi. Prosiding Semirata FMIPA Universitas Lampung (hal. 595-606)

Lie, A. (2008). Cooperative Learning. Jakarta: Gramedia.

Majid, A. (2013). Strategi Pembelajaran. Bandung : Remaja Rosdakarya.

Natawidjaja, dkk. (2007). Rujukan Filsafat, Teori dan Praksis Ilmu Pendidikan. Bandung: UPI Press

Qohar, A. (2009). Pemahaman Matematis Siswa Sekolah Menengah Pertama pada Pembelajaran dengan Model Reciprocal Teaching. Makalah pada Seminar Nasional Matematika dan Pendidikan Matematika Jurusan Pendidikan Matematika FMIPA UNY (P-31).

Rifyal, Y. (2013). Perbandingan Pemahaman Matematis antara Siswa yang Mendapatkan Pendekatan Problem Based Learning dengan Siswa yang Mendapatkan Pembelajaran Langsung. Skripsi pada Jurusan Matematika STKIP Garut : Tidak diterbitkan.

Sukmadinata. (2007). Metode Penelitian Pendidikan. Bandung : PT REMAJA ROSDAKARYA.
Yamin, M. (2013). Strategi dan Metode dalam Model Pembelajaran. Jakarta: Referensi (GP Press Group)

\section{RIWAYAT HIDUP PENULIS}

Dina Nailul Muna, S.Pd. Lahir di Garut,

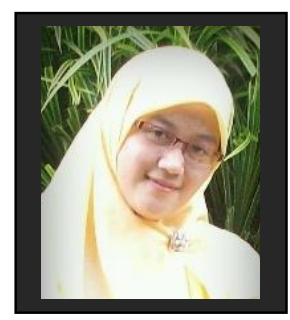
24 November 1993. Studi S1 Pendidikan Matematika STKIP Garut, lulus tahun 2015.

Ekasatya Aldila Afriansyah, S.Si., M.Sc.

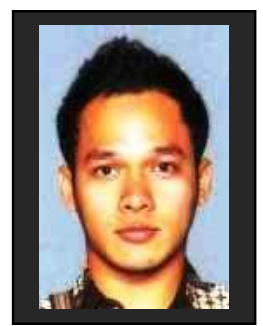
Lahir di Bandung, 4 April 1986. Dosen Tetap Yayasan di STKIP Garut. Studi S1 Matematika Konsentrasi Statistika UPI, Bandung, lulus tahun 2009; S2 Pendidikan Matematika Universitas Sriwijaya-Universitas Utrecht, PalembangUtrecht, lulus tahun 2012; dan S3 Pendidikan Matematika UPI, Bandung, masih sampai dengan saat ini. 